\title{
Standing to Sue for Members of Congress
}

This Note will explore the law of standing to sue for United States senators and representatives. An enormous amount has been written about standing by both commentators and judges; yet the law of standing in federal courts remains "cluttered, confused, and contradictory." 1 Although the subject of standing is narrow and technical it raises fundamental issues concerning federal jurisdiction and judicial power. The law of standing for legislators ${ }^{2}$ is no exception to these statements.

Recent standing decisions in legislators' suits reveal substantial conceptual confusion and inconsistency, even though the actual outcomes of the cases are generally defensible. In four recent cases, standing was denied to legislators, though in three of them the denial of standing was an alternative ground for dismissal. ${ }^{3}$ In several other

1. 3 K. Davis, Administrative LAw Treatise $\$ 22.18$, at 78 (Supp. 1965) [hereinafter cited as Davis Treatise]. The law of standing is doctrinally very elusive. The following works are suggested as an introduction to this esoteric "word game played by secret rules" (Flast v. Cohen, 392 U.S. 83, 129 (1968) (Harlan, J., dissenting)): K. Davis, ADministrative Law; CASEs-Text-Problems 84-88 (5th ed. 1973) [hereinafter cited as Davis Casebook]; 3 Davis Treatise $\$ 22$ (1958, Supp. 1970); L. Jaffe, Judicial Control of AdMinistrative ACTION 459-545 (1965) [hereinafter cited as Jaffe TREatise]; Albert, Standing to Challenge Administrative Action: An Inadequate Surrogate for Claims for Relief, 83 YALE L.J. 425 (1974); Berger, Standing to Sue in Public Actions: Is It a Constitutional Requirement?, 78 YALE L.J. 816 (1969); Bittker, The Case of the Fictitious Taxpayer: The Federal Taxpayer's Suit Twenty Years After Flast v. Cohen, 36 U. Chr. L. REv. 364 (1969); Davis, Standing: Taxpayers and Others, 35 U. CHI. L. REv. 601 (1968) [hereinafter cited as Davis, Others]; Davis, Standing to Challenge Governmental Action, 39 MINN. L. Rev. 353 (1955) [hereinafter cited as Davis, Standing]; Davis, The Case of the Real Taxpayer: A Reply to Professor Bittker, 36 U. CHI. L. REv. 375 (1969) [hereinafter cited as Davis, Reply]; Davis, The Liberalized Law of Standing, 37 U. CHr. L. REv. 450 (1970) [hereinafter cited as Davis, Liberalized]; Jaffe, Comment: Standing Again, 84 HARv. L. REv. 633 (1971); Jaffe, Standing to Secure Judicial Review: Private Actions, 75 Harv. L. REv. 255 (1961) [hereinafter cited as Jaffe, Private]; Jaffe, Standing to Secure Judicial Review: Public Actions, 74 HARv. L. REv. 1265 (1961) [hereinafter cited as Jaffe, Public]; Jaffe, The Citizen as Litigant in Public Actions: The NonHohfeldian or Ideological Plaintiff, 116 U. PA. L. REV. 1033 (1968) [hereinafter cited as Jaffe, Citizen]; Scott, Standing in the Supreme Court-A Functional Analysis, 86 HARV. L. REv. 645 (1973); Sedler, Standing to Assert Constitutional Jus Tertii in the Supreme Court, 7I YALE L.J. 599 (1962); Hearings on S.2097 Before the Subcomm. on Constitutional Rights of the Senate Judiciary Comm., 89th Cong., 2d Sess. (1966) [hereinafter cited as S.2097 Hearings].

2. While this Note focuses on federal legislators, many of the same considerations also apply to suits in federal courts by state legislators. An additional consideration in state legislators' suits involves the intervention of the federal courts in the affairs of state governments; but this issue of federalism should not be viewed as a standing question. This aspect of federalism was presented by the factual settings in both Coleman v. Miller, 307 U.S. 433 (1939), and Trombetta v. Florida, 353 F. Supp. 575 (M.D. Fla. 1973); see pp. 1679-81, 1684 infra.

3. Holtzman v. Schlesinger, 484 F.2d 1307 (2d Cir. 1973) (alternative ground); Gravel v. Laird, 347 F. Supp. 7 (D.D.C. 1972) (alternative ground); Diggs v. Connally, Civil Action No. 773-72 (D.D.C., June 19, 1972) (alternative ground), opinion reprinted in JT. Comm. on Cong. Operations, Final Report Identifying Proceedings and Actions of Vital INTEREST to THE ConGress, 92d Cong., 2d Sess. 555 (1972) [hereinafter cited as 
recent cases, ${ }^{4}$ standing was granted to legislators rather freely on grounds which are incompatible with the four decisions in which standing was denied, and which may not satisfy conventional standing criteria, even as liberalized by the Supreme Court since 1968.5 This doctrinal confusion exacts a price, both in the valuable judicial resources that are wasted in attempting to sort through the present tangled law and in the unmistakable potential for unfortunate substantive results in future decisions. This Note will propose a coherent conceptual framework which will enable federal courts to examine the standing question forthrightly, with little of the present confusion and awkwardness. It will then discuss that framework in the context of the particular question of standing in legislators' suits.

\section{The Present Law of Standing in Federal Courts}

Standing is a doctrine of vague and uncertain contours, its application changing from case to case and from subject matter to subject matter. ${ }^{B}$ It is also a fairly recent arrival in the language of American

JT. Comm. REp.], rev'd on other grounds sub nom. Diggs v. Shultz, 470 F.2d 461 (D.D.C. 1972), cert. denied, 411 U.S. 931 (1973). Environmental Protection Agency v. Mink, Givil Action No. 1614-71 (D.D.C., Aug. 20, 1971) (dismissal of part of lawsuit for lack of standing to sue in official capacity; see discussion pp. 1681-82 infra), opinion summarized in JT. CoMM. REP. 33-34, remanded on other grounds, 464 F.2d 742 (D.C. Cir. 1971), aff'd, 410 U.S. 73 (1973).

4. Mitchell v. Laird, 488 F.2d 611 (D.C. Cir. 1973); Nader v. Bork, 366 F. Supp. 104 (D.D.C. 1973); Trombetta v. Florida, 353 F. Supp. 575 (M.D. Fla. 1973).

5. Since 1968, the Supreme Court has liberalized requirements for standing to sue in a number of areas. The most important liberalizing cases are: Sierra Club $v$. Morton, 405 U.S. 727 (1972); Barlow v. Collins, 397 U.S. 159 (1970); Association of Data Processing Serv. Organizations v. Camp, 397 U.S. 150 (1970); Flast v. Cohen, 392 U.S. 83 (1968). Other recent liberalizing cases are United States v. Students Challenging Regulating Agency Procedures (SCRAP), 412 U.S. 669 (1973); Trafficante v. Metropolitan Life Ins. Co., 409 U.S. 205 (1972); Investment Co. Institute v. Camp, 401 U.S. 617 (1971); Citizens to Preserve Overton Park, Inc. v. Volpe, 401 U.S. 402 (1971); Arnold Tours, Inc. v. Camp, 400 U.S. 45 (1970); Newman v. Piggie Park Enterprises, 390 U.S. 400 (1968); Hardin v. Kentucky Util. Co., 390 U.S. I (1968).

In 1970, Professor Davis could say that the Supreme Court had not denied standing to anyone since it began liberalizing the law of standing in 1968. 3 Davis Treatise, supra note $1, \S 22.00-2$, at 710 ; Davis, Liberalized, supra note 1 , at 457 . This is no longer true. Since 1970, the Court has denied standing to sue in several cases. See O'Shea v. Littleton, 94 S. Ct. 669 (1974); S. v. D., 410 U.S. 614 (1973); Roe v. Wade, 410 U.S. 113 (1973) (standing denied to physician and childless married couple); Laird v. Tatum, 408 U.S. I (1972); Sierra Club v. Morton, 405 U.S. 727 (1972). The Court denied standing to raise an issue in Moose Lodge No. 107 v. Irvis, 407 U.S. 163 (1972). For critical commentary on these cases, see the sources cited in note 1 supra.

6. Justice Douglas recently warned that generalizations about standing to sue are largely worthless. Association of Data Processing Serv. Organizations, Inc. v. Camp, 397 U.S. 150, 151 (1970). As he implied, there is no single law of standing. Standing to sue and standing to raise an issue, though overlapping, are not identical. Requirements for standing also differ according to the posture of the litigants. There is no systematic treatment of these distinctions anywhere in the vast literature on standing. For helpful material, see P. Bator, P. Mishikin, D. Shapiro \& H. Wechsler, HART ANd WechsLer's The Federal Courts and the Federal System 150-214 (2d ed. 1973) [hereinafter cited 
jurisprudence. Raoul Berger says that standing apparently entered our federal law via Frothingham $v$. Mellon ${ }^{7}$ in 1923.8 This is not, strictly speaking, true. First, the word "standing" is nowhere mentioned in the Frothingham opinion. Rather, Justice Sutherland speaks in the traditional vocabulary of the degree of plaintiff's interest in the matter sought to be adjudicated. Second, the considerations discussed by Justice Sutherland were already familiar to American constitutional law. In Mississippi \& Missouri Railroad Co. v. Ward," decided 60 years earlier, the Court allowed the plaintiff to maintain his suit, but stated generally that a plaintiff could not be heard "unless he shows that he has sustained, and is still sustaining, individual

as Hart \&. Wechsler]; 3 Davis Treatise, supra note 1, $\$ 22$ (1958, Supp. 1970); Sedler, supra note 1 .

Further, requirements for standing differ greatly according to the subject matter of the case, e.g., free speech, race, religion, environment, economic regulation. The Court generally grants standing freely in free speech cases. For instance, a criminal defendant is permitted to raise the defense of orerbreadth in a prosecution under $a$ statute impinging upon speech even though his acts could be constitutionally prohibited by a properly drawn statutc. See Plummer v. Columbus, 414 U.S. 2 (1973); Gooding v. Wilson, 405 U.S. 518 (1972); Coates v. Cincinnati, 402 U.S. 611 (1971); Shuttlesworth v. Birmingham, 394 U.S. 147 (1969). The "chilling effect" doctrine grants standing more readily to plaintiffs in free specch cases than would otherwise be available. However, this doctrine appears to be under siege. See O'Shea v. Littleton, 94 S. Ct. 669 (1974); Laird v. Tatum, 408 U.S. I (1972); Younger v. Harris, 401 U.S. 37 (1971); Golden v. Zwickler, 394 U.S. 103 (1969); Dombrowski v. Pfister, 380 U.S. 479 (1965).

In cases involving racial discrimination, the Court has liberally granted standing in order to vindicate minority rights. See Trafficante v. Metropolitan Life Ins. Co., 409 U.S. 205 (1972); Sullivan v. Little Hunting Park Inc., 396 U.S. 229 (1969); Barrows v. Jackson, 346 U.S. 249 (1953); Buchanan v. Warley, 245 U.S. 60 (1917); cf. Moose Lodge No. 107 v. Irvis, 407 U.S. 163 (1972).

In cases arising under the religion clauses of the First Amendment, the Court has shown a conspicuous disregard for ordinary standing limitations on its power to adjudicate disputes. See Board of Educ. v. Allen, 392 U.S. 236 (1968); School Dist. of Abington Township v. Schempp, 374 U.S. 203 (1963); Engel v. Vitale, 370 U.S. 421 (1962): McGowan v. Maryland, 366 U.S. 420 (1961); Doremus v. Board of Educ., 342 U.S. 429 (1952); Illinois ex rel. McCollum v. Board of Educ., 333 U.S. 203 (1948); Everson v. Board of Educ., 330 U.S. 1 (1947). For a critical reaction to the Court's casual treatment of the standing questions in religion cases, see Brown, Quid Custodiet Ipsos Custodes:-The School Prayer Cases, 1963 Sup. CT. Rev. 1. Flast v. Cohen, 392 U.S. 83 (1968), appears to legitimate, by means of the different conceptual basis of taxpayers' suits, the standing results reached by the Court in earlier Establishment Clause cases.

The doctrine of standing is in a somewhat uncertain state in environmental lawsuits. See United States v. Students Challenging Regulatory Agency Procedures (SCRAP), 412 U.S. 669 (1973); Sierra Club v. Morton, 405 U.S. 727 (1972); Citizens to Preserve Overton Park, Inc. v. Volpe, 401 U.S. 402 (1971).

Standing requirements in cases involving economic regulation by the government have traditionally been the most rigid. Recent cases have substantially lowered standing barriers in this area. See Investment Co. Institute v. Camp, 401 U.S. 617 (1971); Arnold Tours, Inc. v. Camp, 400 U.S. 45 (1970); Association of Data Processing Serv. Organizations, Inc. v. Camp, 397 U.S. 150 (1970); Hardin v. Kentucky Util. Co., 390 U.S. 1 (1968). See generally 3 DAvis TREATISE, supra note $1, \S 22$ (1958, Supp. 1970).

7. 262 U.S. 447 (1923).

8. Berger, supra note 1 , at 818-19 relies heavily on, and acknowledges a debt to, Jaffe's groundbreaking historical work: JAFFe Treatise, supra note 1, at 459-545; Jaffe, Private, supra note 1; Jaffe, Public, supra note 1.

9. 67 U.S. (2 Black) 485 (1863). 
damage."10 In Liverpool, New York \&े Philadelphia Steamship Co. v. Commissioners of Emigration, ${ }^{11}$ decided in 1885, the Court acknowledged the necessity of adjudging only the "legal rights of litigants in actual controversies" in constitutional litigation. ${ }^{12}$ And seven years later the Court refused to hear Chicago is Grand Trunk Railway $v$. Wellman ${ }^{13}$ because the plaintiff's interest in the outcome of the case was not genuine; the litigants had brought a friendly suit, and the Court dismissed the action as a request for an advisory opinion beyond the Court's power to render.

Nonetheless, Frothingham v. Mellon does mark the point at which the Court began to pay particular attention to the interest of the plaintiff in the matter sought to be adjudicated. However, the Court's opinion in that case is ambiguous; it is unclear whether the holding was based on a requirement of the Constitution or on considerations of prudent administration of justice. ${ }^{14}$ Only later did the Court decide that the "case or controversy" requirement of Article III of the Constitution mandated, as a separately articulated element, that a litigant have standing, a view it still holds today. ${ }^{15}$

The notion that standing is a separately articulated constitutional requirement is thus not compelled by a long history of constitutional adjudication in the Supreme Court. The doctrine's present function as a limitation on the exercise of federal judicial power was served for many years by a variety of other jurisdictional inquiries under such rubrics as advisory opinion, hypothetical question, collusive or friendly suit, ripeness, and mootness. ${ }^{16}$ The degree of plaintiff's interest in the matter sought to be adjudicated was relevant to the inquiry conducted under these labels, but it was not separately articulated or considered. Since standing's present status as a separate threshold inquiry into the basic jurisdiction of the federal courts is a recent jurisprudential development, it should be evaluated primarily

10. Id. at 492. In what may have been an entirely fortuitous anticipation of modern usage, the defendant had contested the action on the ground that plaintiff did not "stand in a position to maintain this suit." Id. at 491.

11. 113 U.S. 33 (1885).

12. Id. at 39 (dictum).

13. 143 U.S. 339 (1892).

14. This uncertainty is reflected in the literature. See, e.g., Brown, supra note 6, at 15. Senator Sam J. Ervin, Jr., would dismiss the discussion of constitutional grounds in Frothingham. He believes that the Court had stated its real grounds (the prudent administration of justice) but that "Judge Sutherland emulated the bad example we Senators sometimes set and talked too much after that." S.2097 Hearings, supra note 1, at $450-51$.

15. See, e.g., O'Shea v. Littleton, 94 S. Ct. 669, 675 (1974); Association of Data Processing Serv. Organizations, Inc. v. Camp, 397 U.S. 150, 151, 152, 154 (1970).

16. See note 38 infra. 
in terms of its present utility, shorn of the illusion that it has a long and respectable history in federal constitutional adjudication.

The development of standing as a constitutional prerequisite to bringing a lawsuit is paralleled by the development of standing as a separately considered, nonconstitutional element going to the merits of the controversy. Standing in this nonconstitutional sense took the form of a "legal interest" test: The plaintiff was granted standing only if he had a legally protected interest being infringed. The primary function of standing in this sense has been to insulate the activities of the federal government from challenges by private citizens or corporations. ${ }^{17}$ This is particularly evident in many of the early suits brought by business enterprises to challenge exercises of governmental regulatory power. In many cases, the Supreme Court held that plaintiffs had no standing to complain of harm caused by governmental action, even though they might be able to demonstrate that the government's actions were illegal and caused them actual injury. ${ }^{18}$ The Court's decisions meant that these particular plaintiffs had no legally protected interest in securing government behavior which comported with law. Wording these decisions in terms of the law of standing-supposedly a preliminary jurisdictional matter-is puzzling, for they were really decisions on the merits: Plaintiffs did not state a claim upon which relief could be granted. ${ }^{19}$ The constitutional inquiry into the standing requirement imposed by Article III and the nonconstitutional inquiry into the standing requirement necessary for a claim upon which relief can be granted are often merged in judicial opinions. Confusion "twice confounded" 20 is the result.

In recent opinions, the Supreme Court has failed to separate these two aspects of standing. Flast $v$. Cohen ${ }^{21}$ is extremely unclear on this

17. For a discussion of old economic regulation cases, see 3 Davis Treatise, supra note $1, \S 22$.

18. See Davis Casebook, supra note 1 , at $84-86$ (citing as particularly egregious examples, L. Singer \&. Sons v. Union Pac. R.R. Co., 311 U.S. 295 (1940); Perkins v. Lukens Steel Co., 310 U.S. 113 (1940); Atlanta v. Ickes, 308 U.S. 517 (1939); Tennessee Elec. Power Co. v. Tennessee Valley Auth., 306 U.S. 118 (1937)).

19. Professor Wright concisely criticizes this "legal interest" test as follows: "It is frequently said that to have standing the plaintiff must be able to demonstrate injury to a legally protected interest. Such an approach is demonstrably circular: if the plain. tiff is given standing to assert his claims, his interest is legally protected; if he is denied standing, his interest is not legally protected." C. WRIGHT, FEDERAL CourTs 43 (2d ed. 1970). Professor Albert has suggested that the circularity pointed out by Professor Wright be corrected by treating standing as part of "an adjudication of familiar components of a cause of action." Albert, supra note 1, at 426. But see note 103 infra.

20. Berger, supra note 1 .

21. 392 U.S. 83 (1968). 
point, as Justice Harlan acutely observed in his dissent. ${ }^{22}$ In two later cases-Association of Data Processing Service Organizations v. Camp ${ }^{23}$ and Barlow $v$. Collins ${ }^{24}$-the Court formulated a two-tier standard designed to eliminate the difficulties of the legal interest test, which, the Court said, went to the merits. ${ }^{25}$ This effort to avoid ' the merits would imply that the resulting test should go only to standing in the constitutional, jurisdictional sense. Unfortunately, however, the move away from the merits was not complete, for in addition to requiring the constitutional minimum of injury in fact, the Court also required that plaintiff's interest be "arguably within the zone of interests sought to be protected by the statute or constitutional guarantee in question." 26 Moreover, the injury in fact test itself anticipates the merits to some degree. If the Court does not recognize plaintiff's injury as sufficient to confer standing, it is thereby injecting normative notions into the concept of injury in fact, a concept which appears, misleadingly, to be neutral on its face. ${ }^{27}$ Thus the constitutional and nonconstitutional elements of standing continue to be mixed in uncertain proportions in the Court's threshold standing determinations. Sierra Club v. Morton ${ }^{28}$ does not resolve this confusion for it addresses only the injury in fact portion of the Data Processing test.

\footnotetext{
22. Id. at 116 .

23. 397 U.S. $150(1970)$

24. 397 U.S. 159 (1970).

25. 397 U.S. at 153.
}

26. Id. Justices Brennan and White concurred in the result but disagreed with the two-tier test of Data Processing. They would have required only injury in fact. Id. at 168. Professor Davis has also criticized the Data Processing formulation for requiring more than injury in fact, arguing that the "zone of interests" test is, inter alia, analytically faulty, cumbersome, inconvenient, artificial, and contrary to congressional intent. 3 Davis Treatise, supra note 1, $\$ 22.00-5$ at 726 (Supp. 1970); Davis, Liberalized, supra note 1 , at $458-68$.

As applied in Barlow, the Data Processing "zone of interests" test is an inquiry into whether plaintiffs themselves (rather than particular interests they sought to protect) were within the zone of interests. 397 U.S. at 164 . Two subsequent cases suggest that the Court is not taking very seriously the zone of interests test and that the inquiry into the degree of protection intended by Congress is likely to be perfunctory. Investment Co. Institute v. Camp, 401 U.S. 617 (1971); Arnold Tours, Inc. v. Camp, 400 U.S. $45(1970)$. See Albert, supra note 1, at 496; Scott, supra note 1, at 666; Sedler, Standing, Justiciability, and All That: $A$ Behavioral Analysis, 25 VAND. L. REV. 479, 486,487 (1972).

27. See Dugan, Comment: Standing to Sue: A Commentary on Injury in Fact, 22 CASE W. RES. L. REv. 256 (1971). Dugan correctly points out that any attempt by one person to determine whether another has received an injury necessarily involves a normative judgment about what the person "injured" was justified in expecting; he suggests that the only approach which avoids the merits is solipsistic: The party him. self decides whether he is injured (although the court, of course, may decide on the merits that what plaintiff feels as an injury is nevertheless not deserving of compensation). Id. at 266. However, Dugan wrongly suggests that Davis' approach is so"lipsistic for, as Dugan acknowledges, Davis" notion of injury involves "legitimacy" and "deservingness." Id. at 267 n.43.

28. 405 U.S. 727, 733 n.5 (1972). 
The Court's reluctance to clarify the law of standing is perhaps understandable, for the ambiguity of the concept gives the Court flexibility to take, or refrain from taking, jurisdiction of controversial cases. This, in essence, is the argument advanced by Alexander Bickel-that the Court should be able to exercise discretion in determining the cases and issues it will decide, and that the use of various procedural devices to accomplish this aim is a proper exercise of judicial power. ${ }^{20}$ Bickel's argument, however, has its limits. Though he notes the great flexibility of available procedural devices, he states that constraints on employing them inhere in their "intellectual content and intrinsic significance."30

The concept of standing is so muddled, however, that one may wonder if it truly does have any coherent intellectual content. In two prominent cases in which the subject matter was clearly discomfiting to the Court-Tileston v. Ullman ${ }^{31}$ and Laird v. Tatum, ${ }^{32}$ the

29. Underlying this argument are important assumptions about the role of the Supreme Court in constitutional adjudication. The basic paradox that Professor Bickel addresses is that the Court, while part of a democratic government and exercising enormous power, is nevertheless insulated to an extraordinary degree from the pressures of popular wishes. Judge Learned Hand also addressed this paradox. Believing judicial review to be supported by the basic structure of the federal government but not by the explicit text of the Constitution, he grudgingly justified the power of judicial review by such an undemocratic body; however, he granted the legitimacy of judicial review only when necessary "to prevent the defeat of the venture at hand." L. HAND, The Bill of Rights 14 (1958). Herbert Wechsler argues to the contrary that judicial review is explicitly authorized by the words of the Constitution, but he would require that the judicial function be governed by the famous and enigmatic "neutral principles." H. WeCHSLeR, Toward Neutral Principles of Constitutional Law, in Principles, Politics, and Fundamental Law 3-48 (1961). For Professor Bickel's much more complex position, see Bickel, Foreword: The Passive Virtues, The Supreme Court, 1960 Term, 75 Harv. L. Rev. 40 (1961); A. Bickel, The Least Dangerous Branch: 'The Supreme Court AT THE BAR of Politics (1962). In addition, see Deutsch, Neutrality, Legitimacy, and the Supreme Court: Some Intersections Belween Law and Political Science, 20 Stan. L. Rev. 169 (1968); Gunther, The Subtle Vices of the "Passive Virtues"-A Comment on Principle and Expediency in Judicial Review, 64 Colum. L. REv. 1 (1964).

30. A. BICKEL, supra note 29 , at 170 .

31. 318 U.S. 44 (1943). Plaintiff, a doctor, sought a declaratory judgment that Connecticut's birth control statute was unconstitutional, alleging violation of his patients' rights. The Connecticut state courts had upheld the statute on the merits. The Supreme Court dismissed, holding that the doctor lacked standing to assert the rights of his patients. $I d$. at 46 . The rule regarding standing to assert jus tertii was not, however, as clear as the Court's opinion in Tileston implies. See, e.g., Pierce v. Society of Sisters, 268 U.S. 510 (1925); Truax v. Raich, 239 U.S. 33 (1915); Sedler, supra note 1. The Court remained reluctant to decide the issue presented in Tileston for many years, see Poe v. Ullman, 367 U.S. 497 (1961), and did not strike down the Connecticut statute, first challenged in 1945, until 1965. Griswold v. Connecticut, 381 U.S. 479 (1965).

32. 408 U.S. I (1972). Lack of actual or threatened injury served as the basis for dismissal, notwithstanding plaintiffs' claim that their First Amendment rights were chilled. In holding that the plaintiffs had failed to satisfy the requisite test for injury, the Court cited the standing case of Ex parte Levitt, 302 U.S. 633 (1937), despite the significant relaxation of standing requircments that had occurred in the intervening 35 years. In Talum plaintiffs sought injunctive and declaratory relief against the Army's alleged surveillance of lawful and peaceful civilian political activity. The Court, im. plying that plaintiffs had not as individuals been subjected to Army intelligence 
Court used standing as a means to dismiss without reaching the merits. In the other direction, the Court has reached out to decide a number of cases dealing with the Establishment Clause of the First Amendment despite plaintiffs' extremely tenuous claims to standing in any constitutional sense. ${ }^{33}$ Professor Jaffe accurately sums up the Court's treatment of standing: Inconsistent abstentions and interventions have made it impossible to discern a coherent constitutional rationale in the Court's standing decisions. ${ }^{34}$

As demonstrated by Flast, Data Processing, and Sierra Club, the Court is gradually lowering the barrier to judicial relief imposed by standing. It is not clear, however, whether the Court is addressing a basic question of jurisdiction or only one of remedies. The distinction is essential because, if standing is addressed as a constitutional jurisdictional requirement, the Court's inquiry must be made as a prelude to adjudication of the merits; the consideration of plaintiff's standing will be a separately articulated threshold inquiry which must necessarily precede full consideration of the subject matter of the suit. On the other hand, if standing is addressed on the merits as an element of the claim for relief, the consideration of standing will be part of the conventional judicial determination of whether plaintiff is entitled to the relief he has requested. Greater conceptual clarity in the law of standing is essential if the Court is to perform properly the high function of its "great and stately jurisdiction." 35

gathering activities, 408 U.S. at 3, did ignore the explicit statement in the circuit court opinion that the names of most if not all of the plaintiffs appeared in Army intelligence records. See 444 F.2d 947, 954 n.17 (D.C. Cir. 1971). Further, the Court grounded its denial of standing on selective quotations from counsel's oral argument to the effect that plaintiffs were not themselves "chilled." 408 U.S. at 13 n.7. The argument, more fully quoted by the dissent in the court below, makes it clear that counsel was saying only that plaintiffs were not so "chilled" as to be afraid to sue; counsel observed that others were so "chilled" that even filing a lawsuit was too much to undertake. $444 \mathrm{~F} .2 \mathrm{~d}$ at 959 (Mackinnon, J., dissenting). If this is to be taken seriously, Chief Justice Burger seems to be saying that anyone claiming to be "chilled" in his First Amendment rights forfeits his standing to sue by his very act of coming to court. Justice Douglas, in dissent, calls this majority holding "too transparent for serious argument." 408 U.S. at 24.

33. See discussion of these cases in note 6 supra.

34. Jaffe, Public, supra note 1, at 1302. Professor Gunther has criticized Professor Bickel's advocacy of the Court's practice of the "passive virtues" by which it may avoid adjudication of particular cases. He would do better to criticize the Court, whose use, and abuse, of standing go beyond what Professor Bickel seems to have advocated. Gunther, supra note 29. It is interesting to note that although Professor Bickel's emphasis is on the Court's discretion to abstain from adjudication, the flexibility of the procedural devices unavoidably permits the converse-a discretion to abstain is equally a discretion to intervene.

35. Thayer, The Origin and Scope of the American Doctrine of Constitutional Law, 7 HARv. L. REv. 129, 152 (1893). 


\section{A New Conceptual Approach to Standing}

The law of standing can be greatly clarified and may thereby regain its respectability as a concept of federal jurisprudence. The conceptual approach recommended in this Note may be applied to the law of standing generally, but the argument here will be stated and illustrated in terms of the law of standing for United States legislators. The result, based on a sensitive and discerning approach to the importance of the stake of the litigants in the matter to be adjudicated, will be greater precision in judicial analysis and undiminished flexibility in the adjudicatory process.

Standing should no longer be considered a separately articulated and independently investigated threshold jurisdictional requirement imposed by the "case or controversy" limitation of Article III of the Constitution. Professor Jaffe and a number of other legal commentators have argued in support of this step. ${ }^{30}$ Professor Scott sensibly states the proposition most concisely: The fact that a plaintiff cares enough to bring the suit should serve as sufficient proof of his stake in the matter to satisfy any Article III standing requirement. ${ }^{37}$

This does not mean, however, that consideration of the plaintiff's stake in the outcome of the case does not affect a court's jurisdiction under Article III. This Note argues only that standing should cease to be a separately articulated constitutional requirement. A number of other concepts long considered as essential aspects of the case or controversy limitation have elements impinging on the notion of

36. The famous public action is discussed in JAFFE TREATISE, supra note 1 , at 459 500; Jaffe, Citizen, supra note 1; Jaffe, Public, supra note 1. See Monaghan, Constitutional Adjudication: The Who and When, 82 YALE L.J. 1363 (1973); Scott, supra note 1; Sedler, supra note 26.

Professor Davis strongly opposes Professor Jaffe's public action. Davis, Others, supra note 1. Professor Bittker suggests that the Davis and Jaffe positions may be rather similar in their practical effects. See Bittker, supra note 1. But see Davis, Reply, supra note 1 , at 376 n.l.

A possible step in the direction of Professor Jaffe's public action may have been made in Reservists Comm. to Stop the War v. Laird, 323 F. Supp. 833 (D.D.C. 1971) cert. granted, 411 U.S. 947 (1973) (granted standing to plaintiffs, as citizens, to challenge the constitutionality of Defense Department practices permitting United States congressmen to hold reserve commissions in the Armed Forces). See Note, Constitutional Law-Standing of United States Citizens Qua Citizens to Bring Public Actions in Federal Court-Article I, Section 6, Clause 2, 19 WAXNe L. REv. 221 (1972). In addition, see statutes granting standing to anyone who cares to enforce the rights provided by the statute: Clean Air Amendments of 1970, 42 U.S.C. $\$ 1857 \mathrm{~h}-2$ (1970) (any citizen may sue to enforce automobile emission standards); Freedom of Information Act, 5 U.S.C. $\S 552$ (Supp. V, 1970) (any person may sue for information under the Act); statutory creation of a general right to sue also extends to qui tam actions: United States ex rel. Ostrager v. New Orleans Chapter, Associated Gen. Contractors of Am., 317 U.S. 562 (1943); United States ex rel. Marcus v. Hess, 317 U.S. 537 (1943); Marvin v. Trout, 199 U.S. 212 (1905).

37. Scott, supra note $I$, at 673-74. This statement does not apply to collusive suits, where plaintiff pretends that he has an interest opposed to defendant's. Id. at 674. 
standing-advisory opinion, hypothetical question, friendly suit, mootness, and ripeness. ${ }^{38}$ The requirements imposed by these concepts should remain untouched, and to the degree that matters now considered in connection with standing are relevant in determining whether these requirements have been met in any particular case, a court should consider them. But in determining the basic issue of federal jurisdiction, a court should not consider standing as an independent constitutional requirement which must be separately articulated and considered under its own heading. This is not a novel idea. It is, rather, a return to the approach used by the Court before Frothingham.

While standing should no longer be considered separately as part of a jurisdictional inquiry, a plaintiff's stake in the outcome of a dispute should continue to be relevant to the adjudication of the case on the merits. This may involve the very elementary sort of inquiry that can be made at the beginning of a private lawsuit on a motion to

38. See A. BICKEL, supra note 29; HART \& WECHSLER, supra note 6, at 64242; Bickel, supra note 29, at 40; Gunther, supra note 29.

The concepts of advisory opinion, hypothetical question, friendly suit, mootness, and ripeness reflect the basic idea that Article III federal courts should adjudicate only questions presented in concrete cases involving litigants with opposing interests, and that the courts' judgments must be obligatory upon the partics rather than merely advisory. The ban on advisory opinions is frequently defined broadly to subsume the concepts of hypothetical question, friendly suit, mootness and ripeness, but it is often used more narrowly to refer to the courts' refusal to advise other branches of the federal government. See Muskrat v. United States, 219 U.S. 346 (1911) (advice to the legislative branch); $3 \mathrm{H}$. Johnsron, Correspondence and Public Papers of Joln JAY 486-89 (1891) (correspondence of the Justices in 1793 about advice to the executive branch), reprinted in HART \& WECHSLER, supra note 6, at 64-66. The ban on hypothetical questions was at one time thought to preclude declaratory judgments, but it is now conceived to be somewhat narrower. See Willing v. Chicago Auditorium Ass'n, 277 U.S. 274 (1928); cf. Aetna Life Ins. Co. v. Haworth, 300 U.S. 227 (1937). Friendly or collusive suits, in which the parties do not actually have opposing interests, have been dismissed by the Court in United States v. Johnson, 319 U.S. 302 (1943); Chicago \& Grand Trunk Ry. v. Wellman, 143 U.S. 339 (1892). A case becomes moot when an extrajudicial resolution of the dispute deprives a litigating party of an interest in the outcome of the suit. See, e.g., DeFunis v. Odegaard, 94 S. Ct. 1704 (1974); Hall v. Beals, 396 U.S. 45 (1969); California v. San Pablo \& Tulare Ry. Co., 149 U.S. 308 (1893). Ripeness, which is the converse of mootness, requires that events have sufficiently progressed that the litigants' interests are clear and concrete. See Gardner v. Toilet Goods Ass'n, Inc., 387 U.S. 167 (1967); Toilet Goods Ass'n, Inc. v. Gardner, 387 U.S. 158 (1967); Abbott Laboratories v. Gardner, 387 U.S. 136 (1967).

Standing to sue involves consideration of elements of all these concepts, but concentrates on plaintiff's interest in the outcome of the suit he seeks to bring. This Note does not contend that plaintiff's interest in the suit is irrelevant to the issue of the courts' jurisdiction; rather, it suggests only that the confusion which has resulted from the introduction of standing into the vocabulary of federal jurisdiction may be dispelled without sacrificing the underlying utility of the doctrine. In making this suggestion it is difficult to be specific and concrete, for, as Professor Paul Freund has observed, the concept of standing is "among the most amorphous in the entire domain of public law." S.2097 Hearings, supra note 1 , at 498. Professor Jaffe has noted that Justice Frankfurter, in discussing standing, "found himself reduced to a nearly unprecedented degree of inarticulateness." Jaffe, Public, supra note 1, at 1268. 
dismiss for failure to state a claim upon which relief can be granted. ${ }^{30}$ Such a case might be presented, for example, if a wife sought to obtain by a lawsuit benefits to which only her husband was legally entitled. One may as easily decide this case on the ground that the wife lacked standing to assert her husband's rights as decide that the wife was not entitled to relief on the merits of her claim. Regardless of the heading under which the inquiry falls at this early stage, the actual adjudication is clearly made on the merits. ${ }^{40}$ The standing inquiry on the merits may, on the other hand, be part of a complex and subtle decision as to the justiciability, in a nonconstitutional sense, of the question before the court, ${ }^{41}$ and the appropriateness of discretionary equitable relief. ${ }^{42}$ In a case in which the litigants seek equitable relief such as an injunction or a declaratory judgment, the court may consider a variety of factors in determining what relief, if any, is warranted; such factors include the justiciability issues of whether judicially manageable standards are available to determine if a breach of a legal duty has occurred and whether the protection demanded by the litigants may be provided by the forms of judicial remedies available to the court, ${ }^{43}$ as well as those factors which are traditionally pertinent to the exercise of equitable discretion. ${ }^{44}$ Plaintiff's interest in the claim is relevant to these considerations in two respects. First, the degree to which plaintiff would be injured if the

39. Fed. R. Civ. P. 12(b)(6); 2 A Moore's Federal Practice 12.08 (2d ed. 1974). In addition, see FED. R. Civ. P. 12(c), 56; 2A MoOre's Federal Practice I 12.15 (2d ed. 1974); 6 id. I 56.01-.27; Albert, supra note 1, at 431, 497.

40. See HART \& WeChSLER, supra note 6, at 156-57; Albert, supra note 1. Courts occasionally acknowledge this point. See, e.g., Diggs v. Shultz, 470 F.2d 461, 464 n.2 (D.C. Cir. 1972), cert. denied, 411 U.S. 981 (1973).

41. Here, as in much of this tangled area, there are severe definitional problems. Justiciability has often been used to refer both to the amenability to the judicial processes of cases acknowledged to be within the courts' jurisdiction and to the reach of the basic judicial power under Article III. The word is used in this Note in the nonconstitutional sense of amenability to the judicial process. Baker v. Carr, 369 U.S. 186 (1962), draws this distinction:

The distinction between the two grounds [nonjusticiability and the lack of federal jurisdiction] is significant. In the instance of nonjusticiability, consideration of the cause is not wholly and immediately foreclosed; rather, the Court's inquiry necessarily proceeds to the point of deciding whether the duty asserted can be judicially identified and its breach judicially determined, and whether protection for the right asserted can be judicially molded. In the instance of lack of jurisdiction the cause either does not ... fall within one of the . . . enumerated categories of Art. III, $\S 2$, or is not a case or controversy within the meaning of that section; or the cause is not one described by the jurisdictional statute.

Powell v. McCormack, 395 U.S. 486, 512, 513 (1969), reiterates this distinction.

42. Because of the frequency with which it arises, the question of the appropriateness of equitable relief is extremely important. Equitable relief was sought in all the
legislators' suits discussed in this Note.

43. Baker v. Carr, 369 U.S. 186, 198 (1962).

44. See generally O. Fiss, InJunctions 1-155 (1972); W. DE Funiak, Cases on Equitable Relief (1964); W. De Funiak, Handbook of Modern Equity (2d ed. 1956). 
requested relief were denied may properly influence the court to stretch the limits of judicial competence or to grant a discretionary remedy in cases where the denial of relief would impose severe hardship on plaintiff. ${ }^{45}$ Second, in some situations, plaintiff's stake in the matter sought to be adjudicated will correlate with the amount of information that plaintiff can provide to the court about the questions being litigated and about the effects which the court's order would have. ${ }^{46}$ In this more complex decision whether to grant or deny equitable relief, plaintiff's standing is thus relevant to the merits of the controversy and should be so considered.

The advantage of considering plaintiff's interest in the outcome of a dispute only as an element of the merits, and not as a separately articulated element of the court's threshold jurisdictional inquiry, is that the two distinct issues of jurisdiction over the controversy and the merits of the claim will thereby not be confused. These two questions are presently considered together, at a preliminary stage, and often in a confusing manner. This practice may not be particularly harmful when the nonconstitutional standing decision is elementary, the kind ordinarily treated on a motion to dismiss for failure to state a claim. ${ }^{47}$ In such cases, both the jurisdictional and the merits inquiries can easily be made at the beginning of the lawsuit without forcing a premature disposition of the case. A much greater difficulty arises when the question of plaintiff's standing is relevant to a more complex question, such as the granting or denying of equitable relief. In this second, more difficult and subtle decision, the judge will be hampered if he is forced to deal with the merits in a truncated fashion at an early stage of the lawsuit. His decisionmaking task would be much easier if he could postpone all consideration of the plaintiff's interest in the suit until a plenary consideration of the merits of the case.

With only one exception not strictly relevant here, ${ }^{48}$ all of the suits brought by legislators in the last five years are of this second, more difficult variety, in which equitable relief is sought. Prejudging the merits of these cases by a standing determination based in part on an

45. See, e.g., Joint Anti-Fascist Refugee Comm. v. McGrath, 341 U.S, 123, 156 (1951) (Frankfurter, J., concurring).

46. While not strictly an element of the merits of a plaintiff's case, the amount of information available to a court may be a crucial factor in deciding whether a breach of a legal duty may be judicially determined, whether appropriate equitable relief may be judicially molded, and whether equitable relief would be effective and appropriate.

47. See p. 1675 supra.

48. Powell v. McCormack, 395 U.S. 486 (1969). Representative Adam Clayton Powell sued for back pay as well as equitable relief; a suit for back pay is a traditional action at law, and the Court granted standing without discussion. 
anticipation of the merits is awkward and, as shown above, unnecessary. The conceptual framework suggested in the foregoing discussion provides the most sensible approach to the myriad complicated issues which arise in legislators' suits.

\section{Standing for Members of Congress}

Because of both the special representative character of legislators and the place of the legislature in the federal system of government, standing for legislators poses for the judiciary problems beyond those inherent in the general law of standing. This section outlines the distinctive nature of legislators as litigants, critically examines the existing case law, and then analyzes the special problems of legislators' standing in light of the conceptual framework proposed in this Note.

\section{A. A Legislator's Official Capacity as a Basis for Standing}

Although the notion that suits may be brought in capacities other than that of a private individual ${ }^{49}$ is, of course, familiar in AngloAmerican law, ,0 there are special difficulties in the concept that legislators may rely upon their official capacities to justify a grant of standing. First, the nature of this official capacity is unusual. Legislators are the elected representatives of certain portions of the population; they are responsible for voting and otherwise conducting the business of the legislative branch of the federal government. If normal theories of official capacities were applicable, these rights and duties would be, without further question, sufficient to confer standing in a variety of circumstances. ${ }^{51}$ But the fact that a legislator is elected to represent his constituents in the political sense in the legis-

49. Members of Congress nuay, of course, sue as private individuals as well as in their official capacities. Any liberalization of the law of standing for individuals would therefore attomatically liberalize standing to sue for legislators. The concern of this Note, however, is with legislators relying on their official capacities as a justification for a grant of standing.

50. For example, corporations may sue and be sued; trustees in bankruptcy may sue and be sued; administrators of decedents' estates may sue and be sued; persons may sue and be sued under FED. R. Civ. P. 23 as representatives of a class of persons similarly situated; officials of the government may sue and be sued in their official capacities in a wide variety of suits; and governments may sue and be sued-indeed the United States government may sue itself in what Professor Jaffe calls an incestuous suit. See United States v. Interstate Commerce Comm'n, 337 U.S. 426 (1949) (the United States was a defendant with the ICC); Jaffe, Private, supra note 1, at 300. The idea that a legislator may have standing in an official capacity is therefore not without ready analogues. 3A MOORE's FEDERAL PRACTICE $917.16-.25$ (2d ed. 1974).

51. 3A Moore's Federal Practice ff 17.16-.25 (2d ed. 1974); Jaffe, Private, supra note 1 , at 295-302. 
lature does not mean that he may represent his constituents in the legal sense in the courts on the same basis. Moreover, a superficial analogy to a class action under Rule 23 is misleading because a legislator, as a legislator, is not trying to represent other persons similarly situated.

In addition, the rights and duties of federal legislators are inseparably bound up in the affairs of a governmental branch that is coequal with the judiciary. Rather than justifying a grant of standing, one may argue that the official role of a legislator involves sufficient power within the legislature that no expansion of that power through the courts would be appropriate; in Alexander Bickel's phrase, the courts should not be a forum for a replaying of the political game.52

A further difficulty in legislators' suits is the subject matter of the suits themselves. Recent federal cases brought by legislators have raised the following issues: the constitutionality of the Vietnam War; ${ }^{53}$ the legality of ending economic sanctions against Rhodesia; ${ }^{54}$ the validity of a pocket veto over a Christmas recess of the Congress; ${ }^{55}$ the authority of the executive branch to withhold information relating to the nuclear test at Amchitka Island, Alaska; ${ }^{56}$ the legality of firing Watergate Special Prosecutor Cox by Acting Attorney General Bork. ${ }^{57}$ These exceedingly sensitive issues are the sort that the federal courts have traditionally been wary of deciding. While the nature and difficulty of the issues presented in a case have no direct relevance to the doctrine of standing, a court will sometimes impose a more stringent standing requirement in order to avoid taking jurisdiction of a particular suit. ${ }^{58}$

Not surprisingly, the cases dealing with standing for legislators present a confused and uncertain picture. The only Supreme Court case to address the precise question of legislators' standing is 35 years old; ${ }^{59}$ it was decided in an era of restrictive standing doctrine, and its applicability now is questionable. A number of more recent cases deal with questions adumbrated in the early Supreme Court case, but no consistent picture emerges.

52. A. Bickel, Politics and The Warren Court 134 (1965).

53. Schlesinger v. Holtzman, 414 U.S. I321 (1973); Holtzman v. Schlesinger, 414 U.S.

1316, 414 U.S. 1304 (1973); Mitchell v. Laird, 488 F.2d 611 (D.C. Cir. 1973); Drinan

v. Nixon, 364 F. Supp. 854 (D. Mass. 1973); Gravel v. Laird, 347 F. Supp. 7 (D.D.C. 1972).

54. Diggs v. Shultz, 470 F.2d 461 (D.C. Cir. 1973).

55. Kennedy v. Sampson, 364 F. Supp. 1075 (D.D.C. 1973).

56. Environmental Protection Agency $v$ Mink, 410 U.S. 73 (1973)

57. Nader v. Bork, 366 F. Supp. 104 (D.D.C. 1973).

58. See, e.g., suits challenging the legality of the Vietnam War, discussed in note 84 infra. See generally A. BICKEL, supra note 29; Bickel, supra note 29.

59. Coleman v. Miller, 307 U.S. 433 (1939). 


\section{B. Existing Case Law}

In 1939, a split Court decided Coleman v. Miller, ${ }^{60}$ a difficult but important case which implies that legislators may be granted standing in a rather wide variety of circumstances. The case involved a 1924 proposal by Congress to add a Child Labor Amendment to the United States Constitution. In the next year the Kansas legislature adopted a resolution rejecting the proposed amendment. In 1937, thirteen years after the amendment was originally proposed, the Kansas Senate again voted on the amendment, splitting on the issue by a vote of 20 to 20 , all senators voting. The Lieutenant Governor broke the tie by voting in favor of the amendment; the Kansas House of Representatives also approved it. Three representatives and 21 senators, including all 20 who had voted against the amendment, then sued in the Kansas courts, challenging the Lieutenant Governor's right to vote. The Kansas Supreme Court found that his vote was properly cast and denied the suit. The United States Supreme Court took the case on certiorari.

Only five members of the Court agreed that the legislators had standing. Of these five, three joined the majority opinion on the merits, and the other two dissented. Chief Justice Hughes' majority opinion, granting standing to those 20 senators who had originally voted against the amendment, stated that these plaintiffs had a "plain, direct, and adequate interest in maintaining the effectiveness of their votes." 01 On the merits, however, the Chief Justice refused to disturb the decision of the Kansas Supreme Court and held that the significance of Kansas' previous rejection of the amendment and the importance of the 13-year lapse since the original proposal of the amendment were political questions to be resolved by Congress. ${ }^{62}$ Though Chief Justice Hughes' opinion does not explicitly state that the standing decision was made on constitutional grounds, Justice Frankfurter's separate opinion opposing the grant of standing clearly deals with standing as a constitutionally imposed requirement which was not satisfied in this case. ${ }^{63}$

A number of points relevant to the issue of standing for federal legislators emerge from the foregoing summary. First, all 20 of the

60. See Comment, Constitutional Law-Jurisdiction of the Supreme Court-Standing to Sue-Political Question, 39 Colum. L. Rev. 1232 (1939); Comment, The Supreme Court of the United States: Constitutional Amendment, 28 GEo. L.J. 199 (1939).

61. 302 U.S. at 438 .

62. In a separate opinion by Justice Frankfurter, all four Justices who would not have granted standing concurred on the political question ground; they reached the issue only because the other five Justices had granted standing. Id. at 460 .

63. Id. at $460 \cdot 64$. 
defeated senators joined as plaintiffs. It is difficult to assess the importance of this fact to the decision, for the Court did not discuss it. Certainly suits of this sort would be almost nonexistent if unanimous litigiousness were a precondition. However the Court in 1939 would have answered the question, it seems extremely unlikely that the present Court would deny standing in a similar case to a senator merely because he was suing alone. This conclusion is supported by statements in Sierra Club v. Morton ${ }^{64}$ and United States v. Students Challenging Regulatory Agency Procedures (SCRAP) ${ }^{\mathrm{es}}$ that a single individual is not precluded from suing merely because his damage is shared by a number of other persons who do not join in the suit.

In addition, a separation of powers issue arises as soon as the Coleman holding is extended to United States legislators. In Coleman, the plaintiffs were state legislators, ${ }^{, 6}$ and therefore a grant of standing implied no intrusion by the Court into the affairs of a coequal branch of government. But if a federal court decides a case brought by a United States legislator, it risks interfering with the proper affairs of a coequal branch. ${ }^{67}$

Finally, and most importantly, the Court's test, involving an examination of the interest that the legislators have in the effectiveness of their votes, ${ }^{68}$ seems to invite an expansive reading. After citing a number of cases in which private persons' votes had been protected by the Court, Chief Justice Hughes reasoned that the senators' interest in their votes was greater than that of private citizens voting in general elections. ${ }^{69}$ The expansiveness of this approach is indicated by

64. 405 U.S. 727,738 (1972).

65. 412 U.S. 669,686 (1973).

66. Coleman also involves a difficult problem of federalism, to which there is no clear answer. In Coleman, the state legislators sued originally in state court and then sought review in federal court. It may be argued that the Court was encouraged to grant standing since a denial of standing would have had the effect of foreclosing any federal review of an important case involving a federal question. The Court, however, has been erratic in its treatment of standing in cases originating in state courts. For instance, in Tileston v. Ullman, 318 U.S. 44 (1943), the Court's denial of standing left unreviewed a state court ruling on a federal constitutional question. See note 30 supra. Professor Paul Freund has suggested that standing to raise a federal question be itself a federal question in both state and federal courts. Supreme CourT AND SUPREME LAw 35 (E. Cahn ed. 1954). See generally 3 DAvis TREATISE, supra note $1, \$ 22.17$, at 286-91; Davis, Standing, supra note 1, at 423-27.

67. See Powell v. McCormack, 395 U.S. 486, 518-59 (1969).

68. 307 U.S. at 438.

69. Id. at 433, 441, citing Koenig v. Flynn, 285 U.S. 375 (1932); Smiley v. Holm, 285 U.S. 355 (1932); Leser v. Garnett, 258 U.S. 130 (1922); Hawke v. Smith, 253 U.S. 221 (1920). More cases could have been cited by the Court: Carrol v. Becker, 285 U.S. 380 (1932); Nixon v. Herndon, 273 U.S. 536 (1927); United States v. Mosely, 238 U.S. 383 (1915); Ex parte Yarbrough, 110 U.S. 651 (1884); Ex parte Siebold, 100 U.S. 371 (1879). 
the Court's continuing concern for the integrity of individuals' votes, ${ }^{70}$ despite some rather severe strains on traditional notions of the role of the federal judiciary. ${ }^{71}$

Thirty-five years have passed since Coleman was decided, but the issues raised in the case are far from settled. This conclusion is illustrated by six cases decided within the last year, two of which reached the Supreme Court. ${ }^{72}$

Neither of the two Supreme Court cases is very illuminating. In Environmental Protection Agency $v$. Mink, ${ }^{73}$ a suit under the Freedom of Information Act, ${ }^{4 *}$ Representative Patsy Mink and 32 other Members of Congress sought information concerning the forthcoming nuclear test at Amchitka Island, Alaska. The district court dismissed the suit insofar as plaintiffs sought to bring it in their official capacities; and the court of appeals remanded without reaching that issue. ${ }^{\text {To }}$ It is unclear whether the district court intended to decide the standing question in a constitutional sense, or whether it was deciding only the claim that the Freedom of Information Act gave Members of Congress a stronger claim to the information sought than the claim

70. See the Supreme Court's summary of its cases protecting the right to vote, Dunn v. Blumstein, 405 U.S. 330, 336-37 (1972); cf. Comment, The Burger Court and Reapportionment: From One Person, One Vote to One Corporation, Many Votes, 62 Geo. L.T. 1001 (1974).

71. See, e.g., Katzenbach v. Morgan, 384 U.S. 641 (1966); South Carolina v. Katzenbach, 383 U.S. 301 (1966). For discussion of these two cases, see Bickel, The Voting Rights Cases, 1966 Sur. CT. REv. 79; HART \& WECHSLER, supra note 6, at 124-26. See also Baker v. Carr, 369 U.S. 186 (1962); Neal, Baker v. Carr: Politics in Search of Law, 1962 Sup. CT. REv. 252.

72. In three other recent suits brought by legislators, standing was so readily available under traditional principles that the Court did not feel compelled to discuss the issue. One such case was Powell v. McCormack, 395 U.S. 486 (1969). See note 48 supra.

In Roudebush v. Hartke, 405 U.S. 15 (1972), Senator Vance Hartke sued to enjoin a state commission from recounting votes in a close senatorial race that Hartke had won on the first count, and his standing to sue was clearly proper. A number of other cases also arise out of political campaigns and involve allegations of misuse of the congressional franking privilege. Courts have granted standing to opposing candidates to challenge the alleged misuse in each case. See, e.g., Schiaffo v. Helstoski, 492 F.2d 413 (3d Cir, 1974); Hoellen v. Annunzio, 468 F.2d 522 (7th Cir. 1972); Rising v. Brown, 313 F. Supp. 824 (C.D. Cal. 1970); Note, Congressional Perquisites and Fair Elections: The Case of the Franking Privilege, 83 YALE L.J. 1055, 1064-68 (1974).

In Gravel v. United States, 408 U.S. 606 (1972), Senator Mike Gravel filed motions, as intervenor, to quash subpoenas directed to a staff aide and a publisher who were ordered to appear before a grand jury investigating the release of the Pentagon Papers. Gravel asserted immunity under the Speech or Debate Clause of the Constitution. Id. at 609 . The only standing question raised in the case concerned Gravel's standing as intervenor. Id. at 608 n.l. For other cases in which immunity under the Speech or Debate Clause has been raised by defendants, see Doe v. McMillan, 412 U.S. 306 (1973); United States v. Brewster, 308 U.S. 501 (1972); Powell v. McCormack, 395 U.S. 486 (1969); Dombrowski v. Eastland, 387 U.S. 82 (1967); United States v. Johnson, 383 U.S. 169 (1966).

73. 410 U.S. 73 (1973).

74. 5 U.S.C. $\$ 552$ (Supp. V, 1970).

75. 464 F.2d 742 (D.C. Cir. 1971). 
the Act gave to private persons. ${ }^{76}$ The Supreme Court, declining to comment on the point, decided against plaintiffs solely in their roles as private persons. ${ }^{77}$

A more difficult case is Holtzman $v$. Schlesinger, ${ }^{78}$ in which Representative Elizabeth Holtzman and several Air Force officers sought a declaratory judgment and an injunction prohibiting United States combat operations in Cambodia. The district court granted standing because plaintiff's responsibilities as a Representative, including her "continuing responsibility to insure the checks and balances of our democracy through the use of impeachment," gave her the necessary nexus to challenge the action of the executive branch which allegedly infringed unconstitutionally on her congressional duties. ${ }^{79}$ On the merits, the district court found for the plaintiffs and issued an injunction, but postponed the effective date in order to permit defendants to apply to the court of appeals for a stay. ${ }^{80}$ The court of appeals granted the stay without opinion, and plaintiffs filed a motion with Justice Marshall, as Circuit Justice, to vacate the stay order. ${ }^{81}$ Justicc Marshall, acting as a "surrogate for the entire Court," 82 refused to vacate the stay, basing his decision on a finding that there had been no abuse of discretion by the court of appeals. He recognized a standing question raised by the district court opinion, but declined to discuss it. "Lurking in this suit," he said, "are questions of stand-

76. All of the opinions in the Mink case ignored the suggestion in Soucic v. David, 488 F.2d 1067 (D.C. Cir. 1971) (dictum), that the right of a congressman under the Freedom of Information Act is "presumably greater" than that of an ordinary citizen. Id. at 1071 n.6. In Diggs v. Connally, Civil Action No. $773-72$ (D.D.C., June 19, 1972), opinion reprinted in JT. Comm. REP., supra notc 3, at 555, rev'd sub nom. Diggs v. Shultz, 470 F.2d 461 (D.C. Cir. 1972), cert. denied, 411 U.S. 931 (1973), which involved a challenge to the lifting of economic sanctions against Rhodesia, the federal district court treated legislators as private individuals despite plaintiffs' emphasis on their official capacities.

77. The Court observed in a footnote that the issue of the legislators' standing in their official capacities was not before it. 410 U.S. at 75 n.2.

78. Schlesinger v. Holtzman, 414 U.S. 1321 (1973); Holtzman v. Schlesinger, 414 U.S. 1316, 414 U.S. 1304 (1973).

79. Holtzman v. Richardson, 361 F. Supp. 544, 549 (E.D.N.Y. 1973). A similar justification for granting standing was articulated in Mitchell v. Laird, 488 F.2d 611 (D.C. Cir. 1973), and Nader v. Bork, 366 F. Supp. 104 (D.D.C. 1973). See pp. 1684-85 infra.

The statement by the court in Holtzman that standing may be granted because of the plaintiff's duties to vote on the possible impeachment of the President is questionable. The court's determination of the constitutionality of presidential actions may indeed affect the way in which Representative Holtzman would vote on an impeachment resolution, but it is the constitutional role of the Congress, not of the judiciary, to vote on impeachment. Therefore, if a court justifies taking jurisdiction of a case solely by citing the effect its decision could have on an impeachment vote, it is coming close to providing a prohibited advisory opinion to Congress. The Court of Appeals for the Second Circuit, in denying standing to Representative Holtzman, recognized this advisory opinion problem. $484 \mathrm{~F} .2 \mathrm{~d} 1307,1315$ (2d Cir. 1973); see note 38 supra.

80. Holtzman v. Schlesinger, 361 F. Supp. 553 (E.D.N.Y. 1973).

81. 414 U.S. 1304 (1973).

82. Id. at 1313 . 
ing, judicial competence, and substantive constitutional law which go to the roots of the division of power in a constitutional democracy." 83 A divided court of appeals subsequently held that the case presented a nonjusticiable political question; the majority further believed that neither Representative Holtzman nor the servicemen had standing, but noted that this conclusion was not necessary for its decision since the political question issue was dispositive. ${ }^{84}$

Of the four lower court cases, two stay fairly close to the familiar terrain of Coleman v. Miller and two move well beyond. In the former category is Kennedy v. Sampson, ${ }^{85}$ in which Senator Edward M. Kennedy challenged the validity of President Nixon's pocket veto of a bill related to health care. Kennedy had voted for the bill, and, as Chairman of the Senate Subcommittee on Health, had special responsibilities for health legislation. ${ }^{86}$ In granting him standing, the court did not mention his subcommittee responsibility, concentrating instead on the Senator's interest in protecting the effectiveness of his vote. But significantly, the court based standing not only on Kennedy's interest in protecting the efficacy of the vote for the bill which he had already cast, but also on his interest in the vote he would have

83. Id. at 1314. The appellants then applied to Justice Douglas, as Circuit Justice, who granted their motion to vacate the court of appeals' stay. 414 U.S. 1316 (1973). After telephoning all the other Justices, Justice Marshall stayed the district court order directly, with Justice Douglas dissenting. 414 U.S. 1321 (1973).

84. 484 F.2d 1307 (2d Cir. 1973). See note 79 supra. The decision of the court of appeals on the standing and political question issues has never been before the Supreme Court. Justice Marshall did not consider it in refusing to vacate the court of appeals' stay, since at that point the opinion had not yet come down. Moreover, no direct review by the Court was sought, since the combat operations at issue werc terminated shortly after the court of appeals rendered its decision.

Three other suits brought by legislators have also questioned the conduct of the Victnam War. In Drinan v. Nixon, 364 F. Supp. 854 (D. Mass. 1973), the court dismissed the complaint on the ground that it raised a political question, without reaching the standing question. In Gravel v. Laird, 347 F. Supp. 7 (D.D.C. 1972), the court dismissed (1) for lack of standing, (2) because the action involved an unconsented suit against the United States, and (3) because it involved a political question. The third casc, Mitchell v. Laird, 488 F.2d 61I (D.C. Cir. 1973), is discussed at p. 1684 infra.

$A$ body of cases brought by nonlegislators challenging the legality of the Vietnam War is evenly divided between dismissals for lack of standing and dismissals because of a political question. Dismissed for lack of standing: Mottola v. Nixon, 464 F.2d 178 (9th Cir. 1972); Pietsch v. President of the United States, 434 F.2d 861 (2d Cir. 1970), cert. denied, 403 U.S. 920 (1971); Velvel v. Nixon, 415 F.2d 236 (10th Cir. 1969), cert. denied, 396 U.S. 1042 (1970); Campen v. Nixon, 56 F.R.D. 404 (N.D. Cal. 1972). Dismissed on political question grounds: DaCosta v. Laird, 471 F.2d 1146 (2d Cir. 1973); Luftig v. MícNamara, 373 F.2d 664 (D.C. Cir.), cert. denied, 387 U.S. 945 (1967); Atlee v. Laird, 347 F. Supp. 689 (E.D. Pa. 1972), aff'd without opinion, 411 U.S. 911 (1973) (Justices Douglas, Brennan, and Stewart would have noted probable jurisdiction and set the case for oral argument); Davi v. Laird, 318 F. Supp. 478 (W.D. Va. 1970).

In addition, see Justice Douglas' discussion of standing and justiciability in his dissent from denial of a motion for leave to file a bill of complaint in Massachusetts $v$. Laird, 400 U.S. 886 (1970) (Douglas. J., dissenting).

85. 364 F. Supp. 1075 (D.D.C. 1973).

86. This is a subcommittee of the Senate Committee on Labor and Public Welfare. For the jurisdiction of the Committee, see Senate Manual, S. Doc. No. 1, 92d Cong.,
Ist Sess. 36.39 (1971). 
cast to override the veto if the bill had been vetoed in the normal fashion. .7 $^{2}$

While implicitly extending this rationale of protecting the effectiveness of future as well as past votes, Trombetta $v$. Florida ${ }^{88}$ also introduces a new justification for standing in legislators' suits. A provision of the Florida Constitution prohibited voting by legislators on any amendment to the United States Constitution until a majority of the legislature had been elected after the submission of the proposed amendment for ratification. An unspecified number of state legislators ${ }^{89}$ sued in federal district court for a declaratory judgment that this provision conflicted with Articles V and VI of the United States Constitution. The court granted standing and rendered a declaratory judgment that the Florida constitutional provision was invalid. Although not articulated by the court, one of the interests protected by the decision was, as in Kennedy, the right of present legislators to vote on an issue to arise in the future. But the stated rationale of the court was that the legislators had standing because of the "unresolved constitutional dilemma" confronting them, a rationale which may, with its hints of an advisory opinion, ${ }^{90}$ be an even more radical ground for granting standing than protecting a future vote.91

Radical or not, in two other cases standing was granted squarely because of the interest of legislators in knowing whether or not certain activities of defendants were constitutional, so the plaintiffs could cast their votes in the light of that knowledge. In Mitchell $v$. Laird, ${ }^{92}$ thirteen congressmen sued for a declaratory judgment that the Vietnam War was unconstitutional and for an injunction against its continuation. The court explicitly grounded its grant of standing on the effect a declaratory judgment would have on the plaintiffs' duties "to consider whether to impeach . . . , to make appropriations .... , or to take other legislative actions." 93

87. 364 F. Supp. at 1078 .

88. 383 F. Supp. 575 (M.D. Fla. 1973).

89. Though Trombetta concerns state rather than federal legislators, the two possible grounds for standing in the case appear to be equally applicable to suits by federal legislators. In general, many of the issues involved in a standing decision will be the same for both state and federal legislators' suits. An element not present in a suit by state legislators is the possibility that, by deciding a federal legislator's suit, the court might unduly intrude into the affairs of a coequal branch of the federal government. This factor, however, does not dictate that standing in state and federal legislators' suits must be treated differently, for a court may dismiss on political question grounds to avoid intrusion into the affairs of a coequal branch.

90. See note 38 supra.

91. 353 F. Supp. at 576.

92. 488 F.2d 611 (D.C. Cir. 1973).

93. Id. at 614. In Holtzman v. Schlesinger, 361 F. Supp. 544, 549, 550 (E.D.N.Y.), rev'd, 484 F.2d 1307 (2d Cir. 1973), the district court followed this rationale, explicitly citing Mitchell. See note 79 supra. 
A more extreme case than Mitchell is Nader $v$. Bork, ${ }^{04}$ in which a senator and two representatives sued for a declaratory judgment that Acting Attorney General Bork's dismissal of Watergate Special Prosecutor Archibald Cox was illegal. After laconically describing the widespread concern about the administration of justice, the court briefly cited Mitchell as controlling authority and granted standing to the three legislators; ${ }^{95}$ on the merits, the court issued a declaratory judgment against defendant Bork. Though the Mitchell standard is quite permissive, the extraordinary aspect of Nader is not so much the relaxed standing requirement, in itself, as the advisory nature of the opinion ${ }^{90}$ in the circumstances of the case-a case in which Cox was not a party and in which it was not shown that Cox even wanted his job back.

\section{A New Conceptual Approach to Standing for Legislators}

The cases discussed in the previous section, when viewed in light of the Supreme Court's liberalization of standing requirements in other suits, suggest that the Court will impose a rather loose threshold standing requirement when it is squarely faced with a standing question in a legislator's suit. A legislator might be able to meet this relaxed requirement on the basis of his interest in maintaining the effectiveness of his vote, as in Coleman $v$. Miller; ${ }^{97}$ his more general interest in performing particular duties effectively, as suggested, for instance, by the plaintiff in Kennedy $v$. Sampson; 98 or his still more general interest in being sufficiently informed to execute his duties, including voting, as in Mitchell $v$. Laird. ${ }^{99}$

Such an approach would not necessarily be intolerable; the Court might even render the constitutional standing inquiry so perfunctory as to eliminate the standing barrier for legislators in all but a few cases. In other areas of law, twelve cents, ${ }^{100}$ diminution of a vote, ${ }^{101}$ and something that sounds very much like nothing have been suffi-

94. 366 F. Supp. 104 (D.D.C. 1973). Plaintiff Ralph Nader was dismissed from the suit, the court holding that a private person's interest in the dispute was insufficient to confer standing. Id. at 106 n.l.

95. Id. at 105, 106 .

96. See notes 38 \& 79 supra.

97. 307 U.S. 433,438 (1939).

98. Brief for Plaintiff at 18-23, Kennedy v. Sampson, 364 F. Supp. 1075 (D.D.C. 1973). See p. 1683 supra.

99. 488 F.2d 611, 614 (D.C. Cir. 1973).

100. Flast v. Cohen, 392 U.S. 83 (1968).

10I. Baker v. Carr, 369 U.S. 186 (1962). 
cient to support standing. ${ }^{102}$ Yet, if the traditional conceptual approach is followed, there will remain the possibility that a lower court, or even the Supreme Court, will think itself precluded by the Constitution from deciding a dispute suitable for judicial resolution in all respects except that the plaintiff does not meet an independently articulated threshold standing inquiry. ${ }^{103}$ This awkward and unnecessary threshold obstacle to litigation should be eliminated entirely, and standing in the constitutional, jurisdictional sense should no longer be a separately articulated requirement.

A great number of difficult questions surround adjudication of suits brought by legislators, but these questions are better addressed in a nonconstitutional inquiry into justiciability and the appropriateness of granting or denying equitable relief. Many of the same factors considered in the traditional threshold standing inquiry will bear on this equitable decision, but they may be considered more fully and with greater flexibility by the court when seen as part of the merits. ${ }^{104}$

In the past, most courts have found that the interest of legislators in maintaining the effectiveness of their votes was a sufficient basis for a grant of standing. ${ }^{105}$ This interest should continue to be considered as part of the inquiry into justiciability and the appropriateness of equitable relief. Protecting the effectiveness of a legislator's vote as a basis for granting relief is an attractive approach, but its implications are complex. The following considerations should affect a court's decision in a specific case. The legislator seeking to protect a vote already cast probably has the strongest claim for relief, 100 but a persuasive argument may be made that the legislator also has a substantial claim for protection of his right to cast future votes. ${ }^{107}$ Votes not cast may also deserve protection, as, for instance, votes which are "paired" by two legislators with opposing views who agree to abstain from voting. Trading votes on different issues further complicates the issue of whose vote is actually involved. The difficulties of per-

102. See Allied Stores v. Bowers, 358 U.S. 522 (1952) (state taxpayer allowed to challenge exemption of other taxpayers despite the absence of any showing that plaintiff's tax would be reduced by a successful suit); 3 Davis Treatise, supra note $1, \S 22.09-5,-6$ at 746, 753 (Supp. 1970); Davis, Others, supra note 1, at 6]1-17.

103. This possibility remains under Albert's approach. He recommends that standing be seen as "an inadequate surrogate for [a] claim for relief"-that is, a question going to the merits-but he still accepts the conventional idea that standing is a jurisdictional requirement under Article III. This means that the concept of standing would continue to serve its confusing dual function-as both a separately articulated jurisdictional requirement and an element of a claim for relief. Albert, supra note 1 , at 485-86.

104. See pp. 1675-77 supra.

105. See pp. 1679.81, 1684 supra.

106. See Coleman v. Miller, 307 U.S. 433, 438 (1939); Kennedy v. Sampson, 364 F. Supp. 1075, 1078 (D.D.C. 1973); pp. 1679-81, 1684 supra.

107. See Trombetta v. Florida, 353 F. Supp. 575 (M.D. Fla. 1973); p. 1684 supra. 
ceiving whose vote would actually be protected by a grant of judicial relief may lead one to conclude that a legislator should not be obliged to show that he voted in any particular way on the bill in question in order to be granted standing. ${ }^{108}$ This conclusion may be further supported by an argument that a legislator should be able to bring suit to have a bill declared validly passed because of his interest in maintaining proper procedures in all the processes of the legislature, regardless of how he cast his vote on the particular bill.

A legislator's performance of other duties of his office may also merit protection. The claim for relief would probably be strengthened if the duties in question were special responsibilities of the particular legislator, such as the responsibilities of a committee chairman or member or of an officer of either house. The plaintiff suggested this as a ground for standing in Kennedy $v$. Sampson ${ }^{109}$ but the court's opinion ignored his argument; it should, however, be relevant to a determination of the appropriateness of equitable relief in a consideration of the merits.

In addition, a legislator's interest in obtaining information related to the performance of his duties may merit protection. An example of this is the interest in securing factual information from private persons or the executive branch. ${ }^{110}$ However, the situation becomes qualitatively different when the information sought is the judgment of a federal court on the legality of specific legislation or a particular action. At some point, requests for such information stretch the judicial function beyond its proper limits, and the federal judiciary is precluded from rendering such decisions by the prohibition on advisory opinions. ${ }^{111}$

Adoption of the approach to standing outlined in this Note does not mean the federal courts must take jurisdiction of every legislator's suit to come before them; a court may dismiss a suit that asks

108. This argument may, however, be used to support the opposite conclusion. The difficulties of discerning whose vote is actually being denied effect may force a court to decide that it can only protect votes which have clearly been rendered nugatory by the challenged action.

109. Brief for Plaintiff at 18-23, Kennedy v. Sampson, 364 F. Supp. 1075 (D.D.C. 1973). See p. 1684 supra.

110. In relation to the executive branch, such an interest might be protected, for instance, by a statute analogous to the Freedom of Information Act, 5 U.S.C. $\S 552$ (Supp. V, 1970), but with spccial provisions for legislators. See pp. 1681-82 supra.

111. In Muskrat v. United States, 219 U.S. 346 (1911), the Court refused to take jurisdiction of a dispute in which private plaintiffs had been specifically authorized by statute to bring the suit to test the constitutionality of the statutory scheme. The Court's rationale was that the suit requested an advisory opinion. The strength of the Muskrat holding today is somewhat uncertain. Justice Harlan called it a "difficult case," Flast v. Cohen, 392 U.S. 83, 131 n.21 (1968) (Harlan, J., dissenting). See also HART \& WECHSLER, supra note 6, at 124-26 (suggests that South Carolina v. Katzenbach, 383 U.S. 301 (1966), has undermined the Muskrat holding). 
for an advisory opinion or involves a political question. Nor does adoption of this approach mean that if the court does take jurisdiction of the dispute, it is automatically required to grant the relief demanded. Under the suggested analysis, however, standing would no longer be a separately articulated threshold obstacle that prevents a federal court from taking jurisdiction of a legislator's lawsuit. Plaintiff's stake in the suit would be considered as part of a nonconstitutional inquiry into justiciability and the availability of equitable relief, an inquiry in which plaintiff's interest would be evaluated in the context of the entire case to determine the appropriate judicial disposition of the suit.

\section{Conclusion}

Justice Frankfurter once called constitutional law "applied politics, using the word in its noble sense."112 The federal judiciary, while dealing with problems that are in many respects political, must always consider them as legal rather than political problems. That is, judicial power must be emphatically judicial and never merely power.

The danger of contamination of the courts' judicial function by politics in an ignoble sense is raised in a particularly acute fashion when the litigants before the court are themselves politicians. This Note argues that fundamental protection against improper and overreaching exercises of the courts' basic Article III jurisdiction should not come from standing, as it is presently conceived, but should come instead from other jurisprudential concepts which are as well or better suited for this limiting function. For more than one hundred years the present function of standing as a limitation on the exercise of federal judicial authority was adequately performed by a number of other, overlapping doctrines-advisory opinion, hypothetical questions, friendly suits, mootness, ripeness-that are still adequate today.

Standing should not be treated as a separately articulated threshold inquiry going to the basic jurisdiction of the federal courts. So treated, it is an awkward and ill-used concept that is particularly inappropriate as a mechanism for shaping and controlling judicial responses to the difficult, and frequently political, issues raised in legislators' suits. Standing as an independently considered threshold obstacle should be eliminated altogether, and should instead be considered only as part of the merits in the context of the whole case for purposes of molding judicial remedies.

112. F. Frankfurter, Law and Politics 3, 6 (A. MacLeish \& E. Prichard eds. 1939). Bickel agrees with this view. A. BICKEL, supra note 29, at 20; A. BICKEL, supra note 52, at xiî. 